\title{
AKTIVITAS ANTIBAKTERI MINYAK ATSIRI DAUN JERUK PURUT (Citrus hystrix) TERHADAP Staphylococcus aureus DAN Escherichia coli
}

\section{ANTIBACTERIAL ACTIVITY OF VOLATIL OIL OF SMALL AROMATIC LEMON LEAVES (Citrus hystrix) AGAINST Staphylococcus aureus AND Escherichia coli}

\author{
Ratna Yuliani*, Peni Indrayudha, dan Septi Sriandita Rahmi \\ Fakultas Farmasi, Universitas Muhammadiyah Surakarta \\ yulianiratna@yahoo.com
}

\begin{abstract}
ABSTRAK
Jeruk purut (Citrus hystrix) merupakan tanaman dari suku Rutaceae yang telah lama dikenal masyarakat sebagai bahan cita rasa. Hasil penelitian sebelumnya melaporkan bahwa minyak atsiri jeruk nipis (Citrus aurantifolia) memiliki aktivitas antibakteri terhadap Staphylococcus aureus dan Escherichia coli. Penelitian ini bertujuan untuk mengukur aktivitas antibakteri minyak atsiri daun jeruk purut terhadap Staphylococcus aureus dan Escherichia coli dan mendeteksi kandungan minyak atsiri yang mempunyai aktivitas antibakteri. Minyak atsiri daun jeruk purut yang diperoleh dengan cara destilasi uap dan air diuji aktivitas antibakterinya menggunakan metode dilusi cair. Kromatografi Lapis Tipis (KLT) dilakukan menggunakan silika gel $G_{254}$ dan heksan-etil asetat (9:1). Bercak hasil $K L T$ dideteksi dengan $U V_{254} \mathrm{~nm}, U V_{366} \mathrm{~nm}$, anisaldehid-asam sulfat, dan vanilin-asam sulfat. Bioautografi dilakukan dengan metode kontak. Hasil uji aktivitas antibakteri menunjukkan bahwa minyak atsiri daun jeruk purut mempunyai aktivitas antibakteri terhadap Staphylococcus aureus dengan nilai Konsentrasi Hambat Minimum (KHM) dan Konsentrasi Bunuh Minimum (KBM) berturut-turut sebesar 1 dan 2\%. Minyak atsiri juga mampu menghambat dan membunuh Escherichia coli dengan nilai KHM dan KBM $\leq 0,0625 \%$. Hasil KLT menunjukkan bahwa minyak atsiri daun jeruk purut mengandung beberapa senyawa golongan terpen dengan Rf yang berbeda. Berdasarkan hasil bioautografi, salah satu senyawa golongan terpen tersebut mempunyai aktivitas antibakteri terhadap Staphylococcus aureus dan Escherichia coli.
\end{abstract}

Kata kunci : antibakteri, Citrus hystrix, E. coli, minyak atsiri, S. aureus

\section{ABSTRACT}

Small aromatic lemon (Citrus hystrix) is a plant from Rutaceae family that has been known by society as flavoring agent. The result from previous research showed that volatile oil of lemon (Citrus aurantifolia) has antibacterial activity against Staphylococcus aureus and Escherichia coli. The objectives of this research are to measure antibacterial activity of volatile oil of small aromatic lemon leaves against Staphylococcus aureus and Escherichia coli and to determine compounds that have antibacterial activity. Small aromatic lemon leaves volatile oil that was obtained by steam and water distillation was tested for its antibacterial activity using broth dilution method. Thin Layer Chromatography (TLC) was carried out by using silica gel $G_{254}$ and hexane-ethyl acetate (9:1). Spots of silica gel $G_{254}$ were detected by $U V_{254} n m, U V_{366} n m$, anisaldehid - sulfuric acid, and vanillin - sulfuric acid. Bioautography was done by using contact method. The result of antibacterial activity test showed that volatile oil of small aromatic lemon leaves has antibacterial activity against Staphylococcus aureus with Minimum Inhibitory Concentration (MIC) value of $1 \% \mathrm{v} / \mathrm{v}$ and Minimum Bactericidal Concentration (MBC) value of $2 \% \mathrm{v} / \mathrm{v}$. The result of antibacterial activity test against Escherichia coli showed that volatile oil has antibacterial activity with MIC dan MBC values of $\leq$ 0,0625\%. Thin Layer Chromatography results indicated that volatile oil contains several terpenes with different Rf values. Based on bioautography, one of these terpenes has antibacterial activity against Staphylococcus aureus and Escherichia coli.

Keywords: antibacterial, Citrus hystrix, E. coli, S. aureus, volatile oil

\section{PENDAHULUAN}

Infeksi Staphylococcus aureus, anggota

Micrococcaceae, merupakan penyebab utama penyakit pada kulit, jaringan lunak, saluran pernafasan, tulang, persendian, dan endovaskuler. Sebagian besar infeksi tersebut terjadi pada orang dengan faktor resiko multipel
(Lowy, 1998). Kematian yang disebabkan oleh infeksi stafilokokus bervariasi. Bakteremia yang tidak tertangani menyebabkan kematian lebih dari $80 \%$. Angka kematian karena staphylococcal toxic shock syndrome berkisar antara 3 sampai $5 \%$ sedangkan infeksi oleh stafilokokus negatif koagulase hanya 
menyebabkan sedikit kematian (Herchline, 2011). Bakteri lain yang juga dapat menyebabkan infeksi adalah Escherichia coli yang merupakan flora normal pada manusia (Brooks et al., 2005).

Bakteri E. coli merupakan salah satu penyebab tersering infeksi bakteri umum termasuk kolesititis, bakteremia, kolangitis, infeksi saluran kemih, diare pada wisatawan, dan infeksi klinik lain seperti meningitis pada bayi dan pneumonia. $E$. coli merupakan penyebab utama infeksi saluran kemih baik yang diperoleh dari rumah sakit maupun komunitas. Penyebab infeksi pada $50 \%$ wanita yang mengalami infeksi saluran kemih, 4\% kasus diare, dan 12-50\% infeksi nosokomial adalah E. coli. Meningitis pada bayi yang disebabkan oleh $E$. coli sebanyak $8 \%$ sedangkan angka kematian dan angka kejadian terkait bakteremia oleh $E$. coli sama dengan angka kematian dan angka kejadian baksil Gram negatif aerobik (Madappa, 2011). Infeksi yang disebabkan oleh bakteri biasanya diatasi dengan antibiotik yang dapat diperoleh dari sintesis kimia atau mikroorganisme. Untuk mendapatkan sumber antibakteri yang lain, banyak tanaman telah diteliti aktivitas antibakteri in vitro diantaranya jeruk purut.

Beberapa peneliti telah menguji aktivitas antibakteri jeruk purut terhadap banyak bakteri. Chowdhury et al. (2009) melaporkan bahwa ekstrak metanol buah jeruk purut dan beberapa fraksinya mempunyai aktivitas antibakteri dengan tingkat sedang sampai kuat terhadap beberapa bakteri Gram positif dan Gram negatif. Ekstrak etil asetat dan minyak atsiri kulit buah jeruk purut lebih poten terhadap $S$. aureus dibanding $E$. coli (Chanthaphon et al., 2008). Penelitian yang dilakukan oleh Nanasombat dan Lohasupthawee (2005) menunjukkan bahwa ekstrak etanol dan minyak atsiri daun dan kulit buah jeruk purut mempunyai aktivitas antibakteri terhadap beberapa spesies Salmonella dan enterobakteri.Hasil penelitian Luangnarumitchai et al. (2007) mengindikasikan bahwa minyak atsiri kulit buah dan daun jeruk purut mampu menghambat pertumbuhan 5 strain Propionibacterium acne. Penelitian ini bertujuan untuk mengukur aktivitas antibakteri minyak atsiri daun jeruk purut terhadap Staphylococcus aureus dan Escherichia coli dan menentukan golongan senyawa dalam minyak atsiri yang mempunyai aktivitas antibakteri.

\section{METODE PENELITIAN}

Alat: alat destilasi minyak atsiri, piknometer, neraca (Precisa), refraktometer, inkubator (Memmert), autoklaf (China), Laminar Air Flow (LAF), oven (Memmert), lampu $U_{254} \mathrm{~nm}$, dan $\mathrm{UV}_{366} \mathrm{~nm}$.
Bahan: daun jeruk purut yang diperoleh dari Balai Besar Penelitian Pengembangan Tanaman Obat dan Obat Tradisional (B2P2TOOT), Staphylococcus aureus dan Escherichia coli (Laboratorium Mikrobiologi, Fakultas Farmasi, Universitas Muhammadiyah Surakarta), natrium sulfat anhidrat, aseton, Brain Heart Infusion (BHI), Mueller Hinton (MH), PEG 400, alkohol 70\%, silika gel GF 254 , heksana (p.a), etil asetat (p.a), vanilin-asam sulfat, dan anisaldehid-asam sulfat.

\section{Jalannya Penelitian \\ Penyulingan Minyak Atsiri Daun Jeruk purut} Satu kilogram daun jeruk purut segar yang sudah dicuci dan potong-potong dimasukkan ke dalam dandang yang sebelumnya sudah diisi air lalu dipanaskan sampai minyak atsiri keluar. Destilasi dihentikan ketika volume minyak atsiri yang keluar tidak bertambah. Hasil penyulingan dipisahkan dari air dengan menambahkan $\mathrm{Na}$ sulfat anhidrat. Minyak atsiri yang diperoleh disimpan dalam botol yang tertutup rapat dan terlindung dari cahaya.

\section{Uji Antibakteri}

Minyak atsiri sebanyak $4 \mathrm{~mL}$ dilarutkan dalam $96 \mathrm{~mL}$ PEG 400 steril lalu disebut sebagai larutan stok. Enam tabung reaksi steril disiapkan dan masing-masing tabung diisi $1 \mathrm{~mL}$ akuades steril. Tabung pertama diisi $1 \mathrm{~mL}$ larutan stok minyak atsiri lalu dicampur. Campuran dari tabung pertama diambil $1 \mathrm{~mL}$ lalu dimasukkan tabung kedua dan dicampur. Hal tersebut dilakukan secara berulang sampai tabung keenam sehingga diperoleh seri konsentrasi minyak atsiri sebesar 2, 1, 0,5, $0,25,0,125$, dan $0,0625 \%$. Kemudian masingmasing tabung ditambah $1 \mathrm{~mL}$ suspensi bakteri $\left(10^{6} \mathrm{CFU} / \mathrm{mL}\right)$ dalam media BHI. Dalam uji ini, ada 2 kontrol yang digunakan yaitu kontrol media dan kontrol pertumbuhan bakteri. Semua tabung diinkubasi pada suhu $37^{\circ} \mathrm{C}$ selama 24 jam. Setelah inkubasi, dari masing-masing tabung diambil 1 ose suspensi lalu digoreskan pada media $\mathrm{MH}$ dan diinkubasi pada suhu $37^{\circ} \mathrm{C}$ selama 24 jam.

\section{Kromatografi Lapis Tipis}

Silika gel $\mathrm{GF}_{254}$ diaktifkan dengan pemanasan pada suhu $100^{\circ} \mathrm{C}$ selama 1 jam. Larutan uji ditotolkan pada fase diam sebanyak tiga kali totolan, setiap kali totolan dibiarkan sampai kering kemudian dielusi dengan heksan:etil asetat (96:4). Bercak-bercak dideteksi pada $U_{2} V_{254} \mathrm{~nm}, U V_{366} \mathrm{~nm}$, pereaksi semprot vanilin-asam sulfat, dan anisaldehidasam sulfat. 


\section{Bioautografi}

Lempeng hasil KLT ditempelkan selama 20 menit pada media $\mathrm{MH}$ yang telah ditanami bakteri. Lempeng diambil lalu kultur diinkubasi pada suhu $37^{\circ} \mathrm{C}$ selama 24 jam.

\section{Analisis data}

Aktivitas antibakteri minyak atsiri daun jeruk purut terhadap Staphylococcus aureus dan Escherichia coli dinyatakan dalam KHM dan KBM. Kadar Hambat Minimum ditentukan dari konsentrasi minyak atsiri terkecil yang mampu menghambat pertumbuhan bakteri yang ditandai dengan tidak adanya kekeruhan dalam tabung uji sedangkan KBM ditentukan dari konsentrasi terkecil minyak atsiri yang mampu membunuh bakteri yang ditandai dengan tidak adanya pertumbuhan pada media $\mathrm{MH}$ padat.

Hasil KLT yang sudah dideteksi dengan $\mathrm{UV}_{254} \mathrm{~nm}, \mathrm{UV}_{366} \mathrm{~nm}$, pereaksi semprot anisaldehid-asam sulfat, dan vanillin-asam sulfat dihitung nilai Rf-nya lalu dibandingkan dengan literatur. Hasil uji bioautografi yang berupa zona jernih pada bekas bercak lempeng hasil KLT dihitung Rf-nya lalu dibandingkan hasil uji KLT sehingga senyawa yang mempunyai aktivitas antibakteri dapat diketahui.

\section{HASIL DAN PEMBAHASAN}

\section{Hasil Uji Aktivitas Antibakteri}

Hasil uji aktivitas antibakteri menunjukkan bahwa minyak atsiri daun jeruk purut mampu menghambat pertumbuhan dan membunuh $S$. aureus dan E. coli. S. aureus masih dapat tumbuh dengan adanya minyak atsiri daun jeruk purut dengan konsentrasi 0,5, 0,25, 0,125 dan $0,0625 \%$ (Tabel 1). Minyak atsiri dengan konsentrasi 2 dan $1 \%$ sudah mampu menghambat pertumbuhan bakteri $S$. aureus. Konsentrasi minyak atsiri terkecil yang mampu menghambat pertumbuhan $S$. aureus adalah $1 \%$ sehingga konsentrasi tersebut dinyatakan sebagai KHM. Hasil penggoresan kultur dilusi cair ke media $\mathrm{MH}$ yang diikuti dengan inkubasi menunjukkan bahwa minyak atsiri dengan konsentrasi $0,0625-1 \%$ belum dapat membunuh $S$. aureus yang ditandai dengan masih adanya pertumbuhan bakteri pada media MH. S. aureus baru dapat dibunuh oleh minyak atsiri dengan konsentrasi $2 \%$
(Tabel 2). Konsentrasi tersebut merupakan konsentrasi terkecil yang mampu membunuh $S$. aureus sehingga konsentrasi $2 \%$ dinyatakan sebagai konsentrasi bunuh minimal (KBM).Minyak atsiri daun jeruk purut dengan konsentrasi 2, 1, 0,5, 0,25, 0,125 dan 0,0625\% mampu menghambat pertumbuhan $E$. Coli (Tabel 3). Tetapi dari hasil tersebut nilai KHM belum bisa ditentukan dengan pasti karena pada konsentrasi terkecil yang diujikan yaitu $0,0625 \%$ minyak atsiri masih mampu menghambat pertumbuhan bakteri yang ditandai dengan tidak adanya kekeruhan pada tabung yang berarti tidak ada pertumbuhan bakteri. Nilai KHM mungkin 0,0625\% atau lebih kecil lagi. Untuk menentukan nilai KHM secara pasti sebaiknya dilakukan uji dengan konsentrasi minyak atsiri yang lebih kecil. Nilai KBM juga belum dapat ditentukan karena semua konsentrasi minyak atsiri yang diujikan mampu membunuh $E$. coli yang ditandai dengan tidak adanya pertumbuhan pada media MH (Tabel 4). Oleh karena itu, harus ada uji yang menggunakan konsentrasi minyak atsiri yang lebih kecil dari 0,0625\% untuk memperoleh nilai KBM yang pasti.

Hasil uji aktivitas antibakteri terhadap $S$. aureus dan $E$. coli mengindikasikan bahwa Kedua bakteri uji mempunyai sensitivitas yang berbeda terhadap minyak atsiri daun jeruk purut. E. coli lebih mudah dihambat dan dibunuh oleh minyak atsiri daun jeruk purut dibandingkan $S$. aureus. Hal ini dapat dilihat dari nilai KHM dan KBM minyak atsiri terhadap masing-masing bakteri. E. coli sudah dapat dihambat dan dibunuh oleh minyak atsiri dengan konsentrasi kecil yaitu $0,0625 \%$ sedangkan pertumbuhan $S$. aureus baru dapat dihambat dan dibunuh oleh minyak atsiri dengan konsentrasi berturut-turut 1 dan 2\%. Perbedaan sensitivitas bakteri terhadap minyak atsiri daun jeruk purut mungkin disebabkan oleh perbedaan struktur dinding sel antara bakteri Gram positif dan bakteri Gram negatif. Kepekaan bakteri terhadap antibiotik tergantung pada perbedaan susunan dinding selnya misalnya jumlah peptidoglikan, adanya reseptor dan lipid, sifat hubungan silang, aktivitas enzim autolisis yang menentukan penetrasi, ikatan, dan aktivitas obat (Jawetz et al., 1996).

Tabel 1-Hasil Uji Aktivitas Antibakteri Minyak Atsiri Daun Jeruk Purut terhadap S. aureus untuk Menentukan Nilai KHM

\begin{tabular}{cccccccccc}
\hline \multirow{2}{*}{ No } & \multicolumn{4}{c}{ Hasil pertumbuhan bakteri S. aureus pada kadar $(\% \mathbf{v} / \mathbf{v})$} & \multicolumn{3}{c}{ Kontrol } \\
\cline { 2 - 10 } & $2 \%$ & $1 \%$ & $0,5 \%$ & $0,25 \%$ & $0,125 \%$ & $0,0625 \%$ & $\mathrm{KI}$ & $\mathrm{K} 2$ \\
\hline 1. & - & - & + & + & + & + & - & + \\
2. & - & - & + & + & + & + & - & + \\
3. & - & - & + & + & + & + & - & + \\
\hline
\end{tabular}

Keterangan: tanda (+) berarti: terdapat pertumbuhan bakteri, (-) tidak terdapat pertumbuhan bakteri, K1 adalah kontrol media (media BHI $2 \mathrm{~mL}$ ), K2 = kontrol pertumbuhan bakteri (media BHI $1 \mathrm{~mL}+$ suspensi bakteri $1 \mathrm{~mL}$ 
Tabel 2-Hasil Uji Aktivitas Antibakteri Minyak Atsiri Daun Jeruk Purut terhadap S. aureus untuk Menentukan nilai KBM

\begin{tabular}{|c|c|c|c|c|c|c|c|c|}
\hline \multirow{2}{*}{ No } & \multicolumn{6}{|c|}{ Hasil pertumbuhan bakteri S. aureus pada kadar (\%v/v) } & \multicolumn{2}{|c|}{ Kontrol } \\
\hline & $2 \%$ & $1 \%$ & $0,5 \%$ & $0,25 \%$ & $0,125 \%$ & $0,0625 \%$ & $\mathrm{KI}$ & $\mathrm{K} 2$ \\
\hline 1. & - & + & + & + & + & + & - & + \\
\hline 2. & - & + & + & + & + & + & - & + \\
\hline 3. & - & + & + & + & + & + & - & + \\
\hline
\end{tabular}

Keterangan: tanda (+) berarti: terdapat pertumbuhan bakteri, (-) tidak terdapat pertumbuhan bakteri, K1 adalah kontrol media (media BHI $2 \mathrm{~mL}$ ), K2 = kontrol pertumbuhan bakteri (media BHI $1 \mathrm{~mL}$ + suspensi bakteri $1 \mathrm{~mL}$

Tabel 3-Hasil Uji Aktivitas Antibakteri Minyak Atsiri Daun Jeruk Purut terhadap E. coli untuk Menentukan Nilai KHM

\begin{tabular}{|c|c|c|c|c|c|c|c|c|}
\hline \multirow{2}{*}{ No } & \multicolumn{6}{|c|}{ Hasil pertumbuhan bakteri E. coli pada kadar (\%v/v) } & \multicolumn{2}{|c|}{ Kontrol } \\
\hline & $2 \%$ & $1 \%$ & $0,5 \%$ & $0,25 \%$ & $0,125 \%$ & $0,0625 \%$ & $\mathrm{KI}$ & $\mathrm{K} 2$ \\
\hline 1. & - & - & - & - & - & - & - & + \\
\hline 2. & - & - & - & - & - & - & - & + \\
\hline 3. & - & - & - & - & - & - & - & + \\
\hline
\end{tabular}

Keterangan: tanda (+) berarti: terdapat pertumbuhan bakteri, (-) tidak terdapat pertumbuhan bakteri, K1 adalah kontrol media (media BHI $2 \mathrm{~mL}$ ), K2 = kontrol pertumbuhan bakteri (media BHI $1 \mathrm{~mL}+$ suspensi bakteri $1 \mathrm{~mL}$

Tabel 4-Hasil Uji Aktivitas Antibakteri Minyak Atsiri Daun Jeruk Purut terhadap E. coli untuk Menentukan nilai KBM

\begin{tabular}{cccccccccc}
\hline \multirow{2}{*}{ No } & \multicolumn{4}{c}{ Hasil pertumbuhan bakteri E. coli pada kadar (\%v/v) } & \multicolumn{4}{c}{ Kontrol } \\
\cline { 2 - 10 } & $2 \%$ & $1 \%$ & $0,5 \%$ & $0,25 \%$ & $0,125 \%$ & $0,0625 \%$ & $\mathrm{KI}$ & $\mathrm{K} 2$ \\
\hline 1. & - & - & - & - & - & - & - & - \\
2. & - & - & - & - & - & - & - & - \\
3. & - & - & - & - & - & - & - \\
\hline
\end{tabular}

Keterangan: tanda (+) berarti: terdapat pertumbuhan bakteri, (-) tidak terdapat pertumbuhan bakteri, K1 adalah kontrol media (media BHI $2 \mathrm{~mL}$ ), K2 = kontrol pertumbuhan bakteri (media BHI $1 \mathrm{~mL}+$ suspensi bakteri $1 \mathrm{~mL}$

\section{Hasil Analisis KLT}

Berdasarkan hasil KLT, bercak-bercak hasil pemisahan komponen minyak atsiri menunjukkan warna kuning, biru, coklat, dan ungu setelah disemprot dengan vanilin-asam sulfat dan berwarna kuning, ungu, biru, merah, dan oranye setelah disemprot dengan anisaldehid-asam sulfat. Adanya bercak berwarna biru-biru ungu setelah disemprot dengan vanilin-asam sulfat menandakan senyawa monoterpen alkohol dan esternya (Wagner dan Bladt, 1996). Kemungkinan minyak atsiri daun jeruk purut mengandung senyawa golongan terpen dengan nilai $\mathrm{Rf} 0,25$, 0,44 dan 0,63 . Hasil identifikasi dengan metode KLT ini belum dapat menentukan secara spesifik senyawa yang terkandung dalam minyak atsiri daun jeruk purut. Penelitian lain menyebutkan bahwa ada 29 komponen yang teridentifikasi di dalam minyak atsiri daun jeruk purut yang diperoleh dengan cara destilasi air. Minyak atsiri daun jeruk purut terdiri atas monoterpen teroksigenasi dalam jumlah besar yaitu $86,15 \%$ dari total minyak atsiri. Komponen utamanya adalah $\beta$-sitronelal, monoterpen $(66,85 \%$ dari total minyak atsiri) yang diikuti oleh $\beta$-sitronelol, linalool, dan sitronelol (Loh et al., 2011). Berdasarkan hasil penelitian Loh et al. (2011) tersebut, kemungkinan minyak atsiri daun jeruk purut yang digunakan pada penelitian ini juga mengandung komponen yang sama. Hal ini diperkuat dengan hasil KLT yang menunjukkan bercak berwarna biru setelah disemprot dengan vanilin-asam sulfat yang menandakan adanya senyawa sitronelal dan linalool.

\section{Hasil Bioautografi}

Hasil uji bioautografi menunjukkan adanya zona jernih pada $\mathrm{Rf} 0,63$. Spot tersebut diduga merupakan senyawa aktif yang memiliki aktivitas antibakteri. Setelah dibandingkan dengan $\mathrm{Rf}$ hasil $\mathrm{KLT}$, senyawa tersebut merupakan terpen dengan harga $\mathrm{Rf} 0,63$. Senyawa golongan terpen mempunyai aktivitas sebagai antibakteri dengan merusak membran sel dan menghambat pertumbuhan serta mematikan bakteri dengan menggangu terbentuknya dinding sel (Rapilu dan Lamapaha, 2009).

\section{KESIMPULAN DAN SARAN}

\section{Kesimpulan}

1. Minyak atsiri daun jeruk purut mempunyai aktivitas antibakteri terhadap $S$. aureus dengan nilai $\mathrm{KHM}$ dan $\mathrm{KBM}$ berturut-turut sebesar 1 dan $2 \%$.

2. Minyak atsiri daun jeruk purut mempunyai aktivitas antibakteri terhadap $E$. coli dengan nilai $\mathrm{KHM}$ dan KBM $\leq 0,0625 \%$.

3. Golongan senyawa aktif dalam minyak atsiri daun jeruk purut yang mempunyai aktivitas antibakteri terhadap $S$. aureus dan $E$. coli adalah terpen.

\section{Saran}

Perlu dilakukan penelitian tentang aktivitas minyak atsiri daun jeruk purut terhadap $E$. coli dengan konsentrasi minyak atsiri yang lebih kecil dari $0,0625 \%$ sehingga nilai $\mathrm{KHM}$ dan KBM dapat ditentukan dengan pasti. 


\section{UCAPAN TERIMA KASIH}

Penulis mengucapkan terima kasih kepada

Universitas Muhammadiyah Surakarta yang telah memberikan dana untuk melakukan penelitian ini.

\section{DAFTAR PUSTAKA}

Brooks, G.F., Butel, J.S., dan Morse, S.A., 2005, Jawetz, Melnick, and Adelberg's Medical Microbiology, $22^{\text {th }}$ edition, diterjemahkan oleh Mudihardi, E., Kuntaman, Wasito, E. B., Mertaniasih, N. M., Harsono, S., dan Alimsardjono, L., Penerbit Salemba Medika, Jakarta.

Chanthaphon, S., Chanthachum, S., dan Hongpattarakere, T., 2008, Antimicrobial activities of essential oils and crude extracts from tropical Citrus spp. against food-related microorganisms, Songklanakarin J. Sci. Technol., 30 (Suppl.1), 125-131.

Chowdhury, A., Alam, M.A., Rahman, M.S., Hossain, M.A., dan Rashid, M.A., 2009, Antimicrobial, Antioxidant and Cytotoxic Activities of Citrus hystrix DC. Fruits, Dhaka Univ. J. Pharm. Sci., 8 (2): 177-180.

Herchline, T.E., 2011, Staphylococcal Infections, online, (http://emedicine.medscape.com, diakses pada 8 November 2011).

Jawetz, E., Melnick, J. L., dan Adelberg, E. A., 1996, Mikrobiologi Kedoteran, Edisi XX, diterjemahkan oleh Nugroho, E. dan Maulani R. F., 18-21, Penerbit Buku Kedokteran EGC, Jakarta.

Loh, F.S., Awang, R.M., Omar, D., dan Rahmani, D., 2011, Insecticidal properties of Citrus hystrix DC leaves essential oil against Spodoptera litura fabricius, Journal of Medicinal Plants Research, 5 (16), 3739-3744.

Lowy, F.D., 1998, Staphylococcus aureus Infections, The New England Journal of Medicine, 339 (8), 520-532.

Luangnarumitchai, S., Lamlertthon, S., dan Tiyaboonchai, W., 2007, Antimicrobial Activity of Essential Oils Against Five Strains of Propionibacterium acnes, Mahidol University Journal of Pharmaceutical Sciences, 34 (1-4), 60-64.

Madappa, T., 2011, Escherichia coli Infections, online, (http://emedicine.medscape.com, diakses pada 29 November 2011).

Nanasombat, S. dan Lohasupthawee, P., 2005, Antibacterial Activity of Crude Ethanolic Extracts and Essential Oils of Spices Against Salmonellae and Other Enterobacteria, KMITL Sci. Tech. J., 5 (3), 527-538.

Rupilu, N.S., dan Lamapaha, Y.F., 2009, Potensi Lengkuas (Languas galanga) Sebagai Antimikroba (Studi in vitro bakteri Gram negatif,) (online), (http://images.novierupilu.multiply.com/attachment/0/Sc6JhaokCCWAALgG7s1/POTENSI\%LENGK UAS.DOXX?NMID=224430913, diakses tanggal 19 Mei 2009).

Wagner, H. dan Bladt, S., 1996, Plant Drug Analysis, Second edition, Springer. 